\title{
Kiprah Doktor Yusuf Qardhawi \\ Dalam Dakwah dan Gerakan Islam serta Pemikirannya tentang Etika Ekonomi
}

\author{
Muhammad Djakfar \\ Dosen Fak. Ekonomi Universitas Islam Negeri (UIN) Malang, \\ Peserta Program Doktor di IAIN Surabaya
}

\begin{abstract}
Abstrak
The name of Dr. Yusuf Qardhawi is not unfamiliar to the Islamic society as he is a visionary, cosmopolite, and ulema (Ismamic leader) whose thought on religion has been widley used as references. He is quite phenomenal, being a very productive ulema in the universe at the end of the twentieth century up to the beginning of this twenty first century. Therefore, it would be very interesting to conduct an in-depth study on what factors or cross-lines have influenced his productivity, what role he has in the dakwah and Islamic movement, as well as what his thought on economic ethic is. It can be concluded from this discourse that Qardhawi earned his great reputation not only from his individual intellectual capability, but also from an external factor. In this case, the presence of Ikhwanul Muslimin worked as the external factor which has brought him to fame.
\end{abstract}




\section{A. Pendahuluan}

Dalam realitas, peran 'ulama tidak tunggal, dalam arti hanya sebatas di bidang keagamaan an sich. Akan tetapi peran itu jamak sesuai dengan fungsi mereka di tengah komunitas Muslim. Hal ini bisa dipahami karena 'ulama itu pewaris para nabi, sehingga mereka harus menjalankan fungsinya sesuai misi nabi, pewarisnya. Akan tetapi sejalan dengan dinamika zaman dan tuntutan masyarakat, nampaknya peran itu kian menyempit tanpa menghilangkan tugas pokoknya yaitu bidang keagamaan.

Menurut Nurcholish Madjid, bahwa wewenang 'ulama hanyalah di bidang keilmuan atau ilmiah belaka, bukan wewenang keagamaan atau diniyyah. Keterbatasan ini agaknya karena Madjid mempersamakan 'ulama dengan sarjana yang otoritas pokoknya di bidang keilmuan. Tidak demikian halnya menurut pandangan Hiroko Horikoshi yang melihat peran 'ulama dari sebuah realitas melalui penelitian lapangan selama satu tahun, dari bulan September 1972 sampai Agustus 1973, di satu desa dekat kota Garut, daerah Priangan Jawa Barat.' Hasil penelitian yang diberi judul $A$ Traditional Leader in a Time of Change : The Kijaji and Ulama in West Java yang kemudian diterjemahkan ke dalam bahasa Indonesia dengan judul Kyai dan Perubahan Sosial ini Horikoshi membedakan antara peran kyai dan 'ulama.

Peran 'ulama menurut Horikoshi sebagaimana telah dikutip di atas, bisa lebih diperjelas kembali bahwa peran sentral 'ulama adalah di bidang agama dan bertanggung jawab dalam menjaga ortodoksi Islam. Dalam menjalankan perannya ini sebagai pemangku masjid, mereka berfungsi sebagai imam sembahyang dan khotib, di samping sebagai pengajar dan pendidik dalam statusnya sebagai pemangku madrasah dan pondok pesantren yang dibinanya. Selain itu sebagai seorang ahli dan penguasa hukum Islam, ia melayani kegiatan keagamaan secara rutin, memimpin upara keagamaan, menyelesaikan perselisihan di bidang hukum dan pertikaian lainnya, dan sebagainya. ${ }^{2}$

Selanjutnya berkaitan dengan peran 'ulama ini kita coba menggali pendapat Nikki R. Keddie(ed) dalam sebuah karyanya yang berjudul Scholars, Saints, and Sufis. Sebagai editor dalam kumpulan tulisan para pakar ini, dalam kata pendahuluannya, Keddie menyatakan : 
"Meskipun peran dan kekuasaan 'ulama tentunya sangat berbeda menurut waktu dan tempat, dapat dikatakan bahwa 'ulama merupakan sekumpulan orang yang berkuasa (powerful) dan dihormati, yang memiliki sejumlah kekayaan personal maupun perusahaan serta memiliki pengaruh yang besar dalam membentuk masyarakat Islam. Ulama yang melakukan tugas khusus sebagai seorang pengajar, penceramah, atau qadi, menerima penghargaan atas jasa mereka dalam beragam bentuk"3

\section{Selanjutnya, ia menyatakan :}

"Ulama tidak saja sekedar mengatur sejumlah kekayaan tertentu, melainkan juga memiliki pengaruh sebagai pelindung (guardian) bagi hukum, pembelajaran, serta ortodoksi religius. Di samping itu, mereka juga mengelola sekolah-sekolah dari tingkat sekolah dasar hingga perguruan tinggi, lembaga peradilan, rumah sakit, serta lembaga-lembaga amal lainnya"4

Apabila kita tarik garis persamaan dari ketiga sumber di atas sampailah pada suatu kesimpulan bahwa peran pokok 'ulama adalah dalam tataran keagamaan dengan berbagai ragam aktivitasnya, seperti dalam bidang pendidikan, hukum, sosial, ekonomi dan lain sebagainya. Dalam bidang pendidikan, atau pengembangan akademik, mereka mengelola institusi pendidikan mulai dari tingkat dasar hingga perguruan tinggi. Dalam bidang sosial, mereka mengelola rumah sakit, sedangkan dalam bidang advokasi, mereka terlibat dalam lembaga peradilan. Demikian juga dalam bidang kegiatan yang mempnyai nilai ekonomi, mereka mengelola sejumlah kekayaan personal yang dimilikinya dan properti umum (waqaf) yang hasilnya banyak digunakan untuk pengembangan masjid, sekolah atau rumah sakit. ${ }^{5}$

Di luar itu semua, masih ada peran lain yang dimainkan oleh 'ulama antara lain di bidang politik seperti yang digambarkan Keddie bahwa pada abad ke-19 dan pada awal ke-20, para pimpinan 'ulama di Iran menjadi kepala guide spiritual, bahkan juga menyelenggarakan serangkaian protes melawan pemerintahan yang menekan serta melawan pelanggaraan yang dilakukan pihak asing. ${ }^{6}$ Sama halnya dengan apa yang terjadi di Maroko pada masa lalu di mana salah satu peran 
penting para 'ulama adalah merupakan kekuatan pilitis yang sangat berarti. ${ }^{7}$ Peran politik komunitas religious ini saat ini masih menjadi topik pembicaraan yang hangat di beberapa negara Muslim lainnya.

Akhirnya bertolak dari uraian di atas dapat dipahami bahwa peran 'ulama secara realitas historis tidak tunggal, tetapi banyak ranah yang bisa dimainkan di tengah komunitas Muslim, baik di tingkat lokal maupun internasional. Peran-peran mereka tidak sedikit memberi akses berharga dalam pengembangan intelektual (akademik), dakwah, sosial, politik, hukum, dan ekonomi yang hasilnya banyak kita rasakan hingga era modern dewasa ini.

\section{B. Profil Dr. Yusuf Qardhawi ${ }^{8}$}

Tidak salah jika dikatakan bahwa dewasa ini, Qardhawi adalah di antara seorang 'ulama Islam yang sangat populer di kalangan pemerhati masalah keislaman, baik di Timur Tengah maupun di dunia luar.

Sebagai figur 'ulama, rijal al-da'wah wa al- harakah (aktivis dakwah dan gerakan Islam), ia sangat menguasai turats Islam dan non Islam, termasuk aliran pemikiran modern Barat. Karenanya tidak heran kalau ia seakan tidak perriah absen terlibat di forum ilmiah internasional di berbagai negara.

Karena sifatnya yang egaliter (populis) dan jujur, dan didukung kemampuan intelegensi yang tinggi menyebabkan ia mampu duduk berdampingan dan berdialog dengan berbagai kalangan dan kelas.

Qardhawi merupakan putra negeri seribu menara (Mesir). Ia lahir di sebuah desa kecil yang bernama Shafat Turab di tengah Delta pada 9 September $1926 .{ }^{9}$ Sebelum umur sepuluh tahun, ia telah hafal al-Qur'an - sebuah tradisi masyarakat Timur Tengah - khususnya Mesir yang berlangsung hingga saat ini.

Jenjang pendidikannya sejak ibtida'iyah, hingga program doktornya (1973), ia habiskan di Universitas al-Azhar. Disertasinya adalah tentang Al-Zakah wa Atsaruha fi Hal al-Masyakil al Ijtima'iyah (Pengaruh Zakat terhadap Pengentasan Problematika Sosial). Sumber lain mengatakan bahwa Qardhawi menyelesaikan jenjang doktornya tahun 1972 dengan alasan keterlambatannya dalam meraih gelar ini karena ia sempat meninggalkan Mesir akibat kejamnya rezim yang berkuasa saat itu. ${ }^{10}$ 
Aktivitas dalam gerakan Islam, dakwah dan dunia pendidikan begitu padat. Terutama semenjak hijrah ke negara Qatar (1961) sikap pemeritah Mesir saat itu yang sangat tidak bersahabat terhadap dirinya. Sekalipun Qardhawi tinggal di Qatar, ia selalu mengunjungi Mesir negeri kelahirannya, khususnya ketika seminar, kuliah tamu dan dakwah.

Tahun 1961 ia menjabat sebagai direktur ma'had agama tingkat menengah atas - semacam Sekolah Aliyah. Kemudian mendirikan Fakultas Tarbiyah di Universitas Qatar, selanjutnya membidani berdirinya program Islamic Studies (Dirasat Islamiyah) dan menjadi dekannya (1973). Pada tahun 1977 hingga 1989/ 1990 sebagai dekan di dua fakultas, Syariah Islamiyah dan Dirasat Islamiyah. Setahun kemudian (1990/1991), ia dipercaya sebagai direktur Majelis Ilmiyah pusat kajian yang pernah dikomandani Ghazali sebelumnya - dan Ma'had Tinggi Islam di Universitas al-Amir Abdul Qadir al-Jaziri al-Jazair.

Sampai tahun 2000/2001, ia telah melahirkan karya-karya ilmiayah, selain makalah seminar, sebanyak 91 buku. Sebuah prestasi luar biasa yang dialami oleh cendekiawan muslim kontemporer.

Qardhawi juga termasuk 'ulama yang moderat, terbuka dan pakar dalam bidang fikih. Biasanya dalam mengkaji persoalan sosial keagamaan, pendekatan yang diterapkan adalah pendekatan fikih yang sangat fleksibel dan penuh maslahah.

Sebagai 'ulama yang moderat dan terbuka, Qardhawi yang memiliki tujuh anak (empat putri dan tiga putra) sangat demokratis dan terbuka. Ia memberi kebebasan kepada anak-anaknya untuk menuntut ilmu apa saja sesuai dengan minat dan bakat serta kecenderungan masing-masing. Dan hebatnya lagi, dia juga tidak membedakan pendidikan yang harus ditempuh menurut klasifikasi gender. Hal ini tergambar salah seorang putrinya memperoleh gelar doktor fisika dalam bidang nuklir dari Inggris. Putri keduanya memperoleh gelar doktor bidang kimia juga dari Inggris, sedangkan yang ketiga masih menempuh S-3. Adapun yang keempat telah menyelesaikan pendidikan S-1 nya di Universitas Texas Amerika. Anak laki-laki yang pertama menempuh S-3 dalam bidang teknik elektro di Amerika, yang kedua belajar di Universitas Darul Ulum Mesir. Sedangkan yang bungsu telah menyelesaikan kuliahnya pada fakultas teknik jurusan listrik. Dari tujuh anaknya, hanya satu yang belajar di Universitas Darul Ulum Mesir dan menempuh pendidikan agama. Sedangkan yang lainnya, mengambil pendidikan umum di luar negeri." 
Salah satu alasan yang cukup mendasar yang menyebabkan keterbukaan dalam persoalan pendidikan itu, karena Qardhawi merupakan 'ulama yang menolak pembagian ilmu secara dikotomis. Semua ilmu bisa Islami dan tidak Islami, tergantung kepada otrang yang memandang dan mempergunakannya. Pemisahan ilmu secara dikotomis itu, menurut Qardhawi, telah menghambat kemajuan umat Islam. $^{12}$

\section{Dakwah, Gerakan Islam dan Etika Ekonomi : Sebuah Deskripsi}

\section{Dakwah}

Islam adalah agama risalah dan dakwah ${ }^{13} \mathrm{Hal}$ ini sesuai dengan firman Tuhan : " Dan tidaklah Kami mengutus engkau melainkan (menjadi Rasul) untuk membawa berita gembira dan peringatan kepada seluruh umat manusia, akan tetapi kebanyakan manusia tidak mengetahui '(Saba' : 28) $)^{14}$ Dengan demikian inti ayat ini bahwa risalah nubuwah yang diberikan kepada nabi yang membawa misi dari Tuhan adalah dakwah, mengajak pada kebenaran guna meraih kebahagiaan dunia dan akhirat.

Dakwah mengandung pengertian sebagai suatu kegiatan ajakan baik dalam bentuk lisan, tulisan, tingkah laku dan sebagainya yang dilakukan secara sadar dan berencana dalam usaha mempengaruhi orang lain baik secara individual maupun secara kelompok agar supaya timbul dalam dirinya suatu pengertian, kesadaran, sikap penghayatan serta pengamalan terhadap ajaran agama sebagai message yang disampaikan kepadanya dengan tanpa adanya unsur-unsur paksaan ${ }^{15}$. Dengan demikian maka esensi dakwah adalah terletak pada ajakan, motivasi, rangsangan serta bimbingan terhadap orang lain untuk menerima ajaran agama dengan penuh kesadaran demi untuk keuntungan pribadinya sendiri, bukan untuk kepentingan juru dakwah/juru penerang ${ }^{16}$

Tuhan senantiasa mengirim rasul-rasul tertentu ke berbagai wilayah dan umat, selama dunia ini belum memiliki sarana kehidupan sosial dan kultural yang dapat mempersatukan seluruh umat manusia. Akan tetapi tatkala ajaran para rasul telah cukup menggugah kesadaran moral dan sosial manusia untuk hidup di bawah naungan tata kehidupan yang adil yang universal, dan bersamaan dengan 
itu sumber-sumber material dan tata sosial-budaya telah berkembang, yang memungkinkan dakwah dengan mudah menjangkau seluruh pelosok dunia, maka Tuhan Yang Maharahman menganggap sudah tiba saatnya untuk mengirim rasulNya yang terakhir, Muhammad saw ${ }^{17}$ Dan melalui Muhammad, Tuhan mengaruniakan way of life yang sempurna (kafah) selaras dengan karakter, kondisi dan kebutuhan seluruh umat manusia, makhluk ciptaan-Nya. Way of life pemberian Tuhan inilah yang kita kenal dengan Islam, dan esensi Islam ini pulalah yang diwahyukan kepada rasul-rasul sebelum Muhammad.

Karena Muhammad bertanggungjawab membimbing umat seluruh dunia dan menunjukkan kepada mereka jalan yang benar, dan karena tidak ada lagi rasul sesudahnya, maka Tuhan mengangkat Muhammad dengan tugas rangkap khusus, yaitu sebagai rasul untuk bengsa Arab dan untuk seluruh dunia. ${ }^{18}$ Menyebarkan Islam atau menambah jumlah pengikut Islam bukanlah suatu tindakan kebajikan atau ekspresi ketaqwaan semata. Ia adalah kewajiban yang harus dilaksanakan oleh umat Islam keseluruhan. Tugas ini harus dikerjakan oleh setiap individu di dalam komunitas Muslim di manapun dan kapanpun saja. Ia merupakan tugas yang dilimpahkan kepada ummah setelah Nabi wafat. Apabila kaum muslimin menghindar dari tanggungjawab ini berarti mereka mengabaikan kewajiban yang diperintahkan Tuhan. Dan jika demikian, besar kemungkinan Tuhan akan mem-black list mereka dari kedudukan sebagai ummah yang paling baik (khairu ummah), dan menuntut mereka atas tersesatnya umat manusia di dunia ini, karena mereka adalah agen-agen yang memikul tanggungjawab (amanah) untuk membimbing umat manusia dan memberi peringatan kepada mereka. Bila para agen ini tidak melaksanakan fungsinya dengan baik, maka pada yaumul hisab nanti orang-orang dapat mengemukakan alasan kepada Tuhan mengapa mereka tersesat. Mereka tidak akan salah arah dalam hidupnya, seandainya para agen itu berhasil menyampaikan kebenaran sebagai esensi ajaran Islam kepada mereka. Yang dimaksud agen di sini adalah 'ulama sebagai pewaris para nabi (waratsatul anbiyaa), dan termasuk di antara mereka itu, antara lain Dr.Yusuf Qardhawi yang akan dikaji bagaimana kiprahnya dalam menjalankan peran keulama-annya di tengah komunitas muslim, baik dalam tataran dakwah maupun gerakan Islam.

Melalui paparan biografi singkat di atas, Qardhawi telah menempuh beragam pola dakwah, yakni lisan (seminar, ceramah), karya tulis (kutub) dan 
aksi (mendirikan dan memimpin institusi pendidikan keislaman). Dakwah bil lisan, ia lakukan tidak hanya di Qatar di mana ia sekarang menetap, tetapi juga di tempat lain di dunia, seperti Mesir daerah asalnya. Di negeri kelahirannya ini, ia sewaktu-waktu memberi kuliah tamu dan sebagai narasumber di berbagai seminar. Demikian pula dalam wujud dakwah pola ketiga, yang jelas Qardhawi telah banyak berkiprah di Qatar, khususnya di dunia perguruan tinggi. Sedangkan dengan pola dakwah yang kedua ia telah berhasil menorehkan hasil yang sungguh menakjubkan, yaitu berhasil menulis kurang lebih 91 buah karya tulis. Karya ini sudah banyak beredar dan dikonsumsi masyarakat di negeri Islam, termasuk Indonesia.

Untuk membuktikan bagaimana pengaruh dakwah tulis Qardhawi di Indonesia, antara lain bisa dilacak beberapa karyanya yang selama ini beredar, dan bahkan telah diterjemahkan ke dalam bahasa Indonesia dan diterbitkan agar dibaca kalangan luas.

Hasil lacakan tersebut yang telah berhasil didata penulis sendiri, antara lain dapat dikemukakan sebagai berikut :

1. Daurul Qiyam wal Akhlaq fil Iqtishadil Islami (penerbit Maktabah Wahbah, Kairo Mesir, cetakan pertama, 1995 M/1415 H).

2. Fiqhuz Zakat (penerbit Muassasat ar-Risalah, Beirut, Libanon, cetakan kedua tahun 1973).

3. Musykilah Al-Faqr wakaifa 'Aalajaha al Islam (penerbit Maktabah Wahbah, Kairo Mesir, cetakan pertama, 1397 H / 1977 M).

4. Fii Fiqhil Aulawiyyaati Diraasah Jadiidah fii Dhau'il Qur'ani was Sumnati (penerbit Maktabah Wahbah, Kairo, Mesir, cetakan pertama, $1415 \mathrm{H} / 1995 \mathrm{M})$.

5. Al-Madkhal fi-Dirasaat Asy-Syari'ah Al-Islamiyah, sebuah buku daras bagi mahasiswa Fakultas Syari'ah dan Dirasah Islamiyah Jami' ah Qathar.

6. An Naas wal Haq (penerbit Al-Maktabul Islamy, Beirut).

7. Al-Muslimun wal-'Aulamah (penerbit Daar Attauzi' wa Annasyr alIslamiyah).

8. Ad-Din fi 'Asr al-"Ilm (merupakan kumpulan tulisan Qardhawi dalam majalah Manarul Islam) 
9. Risalat Al-Azhar (penerbit Maktabah Wahbah, Kairo Mesir, cetakan pertama, $1404 \mathrm{H} / 1984 \mathrm{M}$ ).

10. Mudzakkirah Duktur Yusuf Qardhawi (Hayati Ma'a Al-Ikhwan AlMuslimun) (merupakan kumpulan catatan harian penulisnya)

11. Arbabul Bunuk bainal Halal wal Haram, Tafsiru Aayaatir Riba (disusun bersama Asy Syahid Sayyid Qutb, Shalah Muntashir, dkk, diterbitkan oleh Darus Syuruq, Kairo, 1987 dan Darul Ma'arif, Mesir, 1989)

12. Nahwa Wahdah Fikriyah lil 'Amilin lil Islam ( Maktabah Wahbah, Kairo, Mesir).

13. Ash Shahwah Al Islamiyah, Bainal Ikhtilafil Masyru' wat Tafarruqil Madzmum ( Daarush Shahwah lin Nasyri wat Tauzi', cetakan pertama, 1411 H / 1990 M, Kairo, Mesir).

14. Awlawiyyat Al Harakat Al Islamiyyah fi Al Marhalah Al Qadimah ( Maktabah Wahbah, Kairo, Mesir, 1411 H / 1991 M).

Itulah antara lain torehan dakwah Qardhawi dalam wujud karya tulis yang berhasil direkam oleh penulis yang selama ini banyak beredar di Indonesia atas jasa beberapa penerbit buku-buku Islam. Pencantuman beberapa karya di atas dimaksudkan sebagai bukti konkret untuk lebih meyakinkan kita betapa besar kiprah Qardhawi dalam memainkan peran keulamaaannya dalam mensosialisasikan ajaran Islam yang tidak saja dikenal di dunia Arab, bahkan juga telah dikenal keseluruh antero dunia, khususnya dunia Islam, seperti Indonesia.

\section{Gerakan Islam}

Yang dimaksud dengan Gerakan Islam ialah segala aktifitas rakyat yang bersifat bersama (jama'ah) dan terorganisasi, yang berupaya mengembalikan Islam agar kembali memimpin masyarakat yang mengarahkan kehidupan mereka dalam segala aspeknya. ${ }^{19}$ Dengan demikian, Gerakan Islam yang paling utama dan pertama sekali adalah sebuah aktifitas. Aktifitas yang berkesinambungan dan tidak mengenal berhenti. Aktifitas yang bukan hanya bicara, khutbah, ceramah, 
buku, seminar dan makalah, kendati semua itu memang perlu, tapi itu hanyalah bagian dari gerakan, dan bukan gerakan itu sendiri. ${ }^{20}$

Khusus kiprah Qardhawi dalam gerakan Islam ini, penulis mencoba menggali dari buku Qardhawi sendiri : Mudzakkirah Duktur Yusuf Qardhawi (Hayati Ma'a Al Ikhwan Al Muslimun) yang telah diindonesiakan dengan judul Kenanganku Bersama Ikhwanul Muslimin. Di samping dari sumber lain yang relevan.

Sebelum sampai pada uraian lebih jauh tentang kiprah Qardhawi, terlebih dahulu perlu dipernalkan tentang Al-Ikhawan Al-Muslimun. Ikhwan adalah sebuah gerakan Islam terbesar di zaman modern ini. Seruannya ialah kembali kepada Islam sebagaimana yang termaktub di dalam Al-Qur'an dan As-Sunnah serta mengajak kepada penerapan syari' at Islam dalam kehidupan nyata ${ }^{21}$. Atau lebih tegas lagi sebagaimana disebutkan dalam Risalah “Akidah Kami”, salah satu dokumen Ikhwan : "Saya yakin bahwa cara mengatasi keterbelakangan umat Islam dan jatuhnya mereka dari agama adalah dengan kembali kepada ajaranajaran Islam dan hukum-hukumnya. Hal ini hanya mungkin sekali dilakukan apabila kaum muslim sendiri menginginkannya. Sementara konsep Ikhwanul Muslimin bertujuan untuk merealisasikan hal tersebut"22Dalam kenyataannya, gerakan ini telah mampu membendung gelombang sekularisasi di dunia Arab dan Islam. Pendirinya adalah Syaikh Hasan al-Banna (1324 - 1368 H / 1906 - 1949 M). Lahir di sebuah kampung di kawasan Buhairah, Mesir. Ia tumbuh di dalam lingkungan yang taat beragama, yang memperaktekkan Islam secara nyata dalam seluruh aspek kehidupannya. Setelah tamat dari Dar al-'Ulum, ia menjadi guru pada sebuah sekolah dasar di Isma'iliyah dan dari tempat inilah ia mengawali aktivitas keagamaannya di tengah-tengah masyarakat.

Dzul Qa'idah $1327 \mathrm{H} /$ April $1928 \mathrm{M}$ adalah bulan didirikannya cikal bakal gerakan Ikhwan. Selama tiga tahun pertama, sejak didirikannya Ikhwan di kota Isma'iliyah, (1928-1932), dakwah Islam dengan cepat diterima masyarakat. Bertambahnya orang yang tertarik terhadap gerakan Ikhwan telah mendorong Al-Banna untuk mengembangkan organisasinya ke wilayah lain. Pada 1932, AlBanna meminta pusat pergerakan di pindahkan ke Kairo, sementara pengembangan organisasi di Isma'iliyah diteruskan oleh para anggotanya, dengan selalu mengadakan konsolidasi kepada pimpinan pusat di Kairo ${ }^{23}$ 
Menyebarnya lkhwan dengan cepat di kalangan masyarakat tidak bisa dipisahkan dari profil Hasan Al-Banna yang mampu mengantarkan gerakannya go public, mewarnai gerakan dakwah lainnya, yang ia formulasikan dalam konsepnya yang komprehensif dan fleksibel ${ }^{24}$. Gerakan Ikhwan dari Kairo tersebar ke berbagai pelosok dan kota di Mesir. Akhir tahun 40-an, cabang Ikhwan di Mesir sudah mencapai 3000 cabang. Tiap cabang memiliki anggota yang cukup banyak. Gerakan tersebut kemudian meluas ke negara-negara Arab. Ia berdiri kukuh di Suriah, Palestina, Yordania, Libanon, Irak, Yaman dan lain-lain. Dewasa ini anggota dan simpatisannya tersebar di berbagai penjuru dunia. ${ }^{25}$

Pemahaman Ikhwan terhadap Islam bersifat universal, tidak mengenal adanya pemisahan antara satu aspek dengan aspek lainnya. Kaitannya dengan dakwah Ikhwan, Hasan Al-Banna mengatakan, "Gerakan Ikhwan adalah dakwah salafiyah, thariqah sunniyah, haqiqah shufiyyah, lembaga politik, klub olah raga, lembaga ilmiah dan kebudayaan, perserikatan ekonomi dan pemikiran sosial'"26 Selain itu Al-Banna menyebutkan karakteristik Ikhwan sebagai berikut :

Gerakan Ikhwan adalah adalah gerakan Rabbaniyyah. Sebab asas yang menjadi proses sasarannya ialah mendekatkan manusia kepada Rabb-nya.

Gerakan Ikhwan bersifat 'alamiyah (internasional). Sebab arah gerakan ditujukan kepada semua umat manusia.

Gerakan Ikhwan bersifat Islami. Sebab orientasi dan nisbatnya hanya kepada Islam ${ }^{27}$

Selain itu juga Al-Banna menetapkan tingkatan amal yang merupakan konsekuensi logis setiap anggota, antara lain memotifasi masyarakat untuk menyebarkan kebaikan, memerangi kemungkaran dan kerusakan ${ }^{28}$ Inilah antara lain isi dakwah yang harus dilakukan di tengah masyarakat agar mereka mau kembali kepada ajaran Islam yang benar yang dituntunkan Allah melalui rasulNya, Muhammad saw. Al-Banna mampu membangun konsepsi-konsepsi dakwahnya yang sesuai dengan kebutuhan zaman dan lingkungan. Sehingga dakwahnya mampu menghadapi berbagai arus yang melanda Mesir dan kawasan lain $^{29}$

Awal persentuhan Qardhawi dengan Ikhwan bersemai sejak duduk di bangku sekolah agama. Ia mengagumi seorang tokoh ulama yaitu Syaikh Al Bahi Al Khuli, gurunya yang sempat mengajar mata pelajaran mahfuzat dan geografi, 
di samping juga banyak mereguk ilmu lewat forum pengajian yang ia pimpin. Syaikh Al-Bahi adalah ketua bidang penyebaran dakwah di Maktab Idari Ikhwan wilayah Barat. Al-Bahi termasuk juru dakwah senior yang biasa menyampaikan pengarahan dan nasehat di kantor Ikhwan secara berkala. Isi pengarahan dan nasehat itu kemudian dikumpulkan dan disebarkan dalam sebuah buku yang berjudul Tadzkiratu Du'at. Isinya diajukan kepada Al-Banna sebagai Mursyid 'Am Ikhwan dan dijadikan sebagai bagian dari Rasail Ikhwanul Muslimin. ${ }^{30}$ Menurut Qardhawi, Al-Bahi dikenal sebagai orang yang mempunyai perenungan dan intuisi yang dalam terhadap Al-Qur'anul Karim, bahkan ia adalah sosok yang memiliki ketinggian ruhani yang jarang dimiliki orang lain. Betapa dalam kesan Al-Bahi dalam hati Qardhawi dan betapa erat hubungan emosional dengan gurunya itu, sampai akhirnya keluarlah sebuah pernyataan tulus dari Qardhawi : “... aku adalah muridmu yang jujur dalam membaca ketabmu yang unik Tadzkiratu Du'at (Catatan Para Juru Dakwah). Aku bersama oarng-orang Rabbani, bukan bersama orang-orang Rahbani (pendeta) yang mengklaim menyerukan diri sebagai wakil Tuhan" 31

Ketika di bangku sekolah agama, Qardhawi memiliki agenda dakwah yang sangat padat. Ia aktif dalam dua bidang pada organisasi Ikhwan yakni bidang pelajar dan bidang penyebaran dakwah. Ia bertugas menyebarkan dakwah di sektor Barat, di Thanta. Banyak para anggota Ikhwan di daerah yang memintanya berkunjung ke tempat mereka. Sampai-sampai koordinator dakwah di Thanta mengatakan : "Apa yang akan kita lakukan dengan permintaan yang begitu banyak dan berulang-ulang ini ? Engkau telah mencuri hati mereka ?"32 Betapa padat kegiatan dakwah Qardhawi di kalangan Ikhwan, sebagaimana pernyataannya :

"Ini adalah curahan nikmat yang sangat besar dari Allah bagiku. Allah SWT memberikan kecintaan para hamba-Nya untukku. Padahal aku poribadi merasa tidak berhak mendapatkan kecintaan yang begitu besar dari mereka. Semoga Allah SWT mengampuni kesalahan-kesalahanku yang tidak mereka ketahui. Ada beberap tempat yang berulangkali dan lebih banyak meminta kehadiranku ketimbang daerah lain. Seperti Kfar Syaikh dan Basiyun. Bahkan aku juga diminta datang di luar wilayah Barat, seperti di Syabin Kum, Tala, Quisna, kota Al Mansurah dan lain-lainnya"33

Sebagai konsekuensi seorang aktivis Ikhwan banyak pengalaman berharga yang menempa sikap tegar dan militansi diri Qardhawi. Antara lain ia rela masuk 
penjara yang pada mulanya penjara Ath Thur, kemudian ke penjara Haiktasib, sampai kemudian dikembalikan lagi ke penjara Ath Thur. Selama di penjara itu, Qardhawi banyak memperoleh hikmah karena bisa bertemu, sekaligus menimba ilmu dari tokoh-tokoh Ikhwan senior yang dikagumi, seperti Syaikh Muhammad Al-Ghazali dan Syaikh Sayyid Sabiq. Sampai akhirnya Qardhawi dibebaskan dari penjara, tepatnya, Maret 1954, ia kembali menjadi manusia merdeka dan melakukan aktivitas seperti biasa sebagaimana pernyataannya :

"Aku tetap melakukan aktivitasku seperti biasa dengan para Ikhwan. Baik di bagian kemahasiswaan, di bagian penyebaran dakwah, atau juga di bagian hubungan dengan dunia Islam. Ini kegiatan yang kami lakukan setelah kami dibebaskan dari tahanan dan pernyataan Abdul Nasher serta tokoh revolusi untuk melakukan rekonsiliasi dengan Ikhwan"34

Sebagai salah seorang tokoh Ikhwan, Qardhawi merasa terpanggil untuk mengajukan otokritik (an naqdu dzati) atau evaluasi diri (muhasabatun nafs) bagi Ikhwan demi kemajuan dakwah yang dilakukannya di masa mendatang. Saran otokritik yang dikemukakan Qardhawi dapat disimpulkan ${ }^{35}$, pertama, hendaknya Ikhwan mencetak kader para da'i tentang apa yang harus mereka baca dan mereka persiapkan untuk pertemuan atau ceramahnya di berbagai tempat. Maksudnya, perlu diprogram tema-tema dakwah yang relevan dan variatif, termasuk perlu ada program evaluasi bagi para da'i yang telah melakukan dakwah di berbagai tempat itu, setiap tiga bulan, enam bulan atau satu tahun sekali. Kedua, dengan kenyataan poin pertama di atas, Qardhawi menyimpulkan adanya kekurangan aspek wawasan ilmiah di kalangan anggotanya. Oleh karena itu saran yang diajukan adalah mereka melakukan pengkaderan melatih menulis karya ilmiah, menambahkan pengarahan mereka untuk menjadi para khatib yang lebih berkualitas dan mengarahkan untuk belajar bahasa Inggris.

Dengan saran itu diharapkan agar Ikhwan memiliki pemikiran strategis yang dilanjutkan oleh para pemuda mereka, kemudian difungsikan sebaik mungkin untuk meningkatkan potensi dan kemampuan mereka secara khusus di berbagai bidang. 


\section{Etika Ekonomi}

Di samping dakwah dan gerakan Islam, sumbangan pemikiran Qardhawi yang pantas diperhitungkan adalah pemikirannya tentang etika ekonomi yang berumber dari Al-Qur'an dan Hadits. Pemikiran ini dituangkan dalam bentuk sebuah karya tulis yang bertitel Daurul Qiyam wal Akhlaq fil Iqtishadil Islami yang diterbitkan oleh penerbit Maktabah Wahbah, Kairo Mesir tahun 1995/1415 H. Karya ini cukup monumental karena tidak saja dikenal di negeri asalnya, Mesir, bahkan di kalangan dunia Islam seperti Indonesia, buku tersebut di diterjemahkan ke dalam bahasa Indonesia oleh K.H. Didin Hafidhuddin, M.Sc, dkk dengan judul Peran Nilai dan Moral dalam Perekonomian Islam.

Sebelum buku itu disusun oleh Qardhawi, nampaknya belum ada karya etika ekonomi yang berbasis Islam yang dapat dikatakan relatif lengkap yang mempunyai bobot akademik yang memadai. Menurut sepengetahuan penulis baru ada sebuah karya, hasil penelitian Mustaq Ahmad dalam bentuk disertasi dengan titel asli Business Ethics in Islam yang diterbitkan oleh The International Institute of Islamic Thought (IIIT) Pakistan. Buku ini pun telah diindonesiakan oleh Samson Rahman dengan judul Etika Bisnis dalam Islam dengan penerbiit Pustaka AlKautsar.

Sejalan dengan maju pesatnya perkembangan ekonomi Islam di Indonesia dewasa ini, karya Qardhawi benar-benar mendapat respons positif dari berbagai kalangan. Karya itu menjadi rujukan pokok baik di kalangan akademisi maupun para praktisi ekonomi Islam. Dalam arti, guna mengisi kekosongan referensi tentang buku-buku etika ekonomi sebelum ini, buku itu menjadi bahan bacaan utama di berbagai perguruan tinggi di Indonesia maupun masyarakat luas, terutama bagi mereka yang bergumul di dunia bisnis. Hal ini bisa terjadi karena dilihat dari aspek isinya dianggap memadai dalam menjawab persoalan-persoalan etika di tengah maraknya sistem perekonomian modern dewasa ini yang banyak mengundang masalah dan membutuhkan acuan pemecahan.

Qardhawi menegaskan bahwa :

"Hal yang membedakan antara sistem Islam dengan sistem maupun agama lain, adalah bahwa antara ekonomi dan akhlak tidak pernah terpisah sama sekali seperti halnya tidak pernah terpisah antara ilmu dan akhlak, antara politik dan akhlak, dan antara perang akhlak. Akhlak adalah daging dan urat nadi kehidupan Islami. Karena risalah Islam adalah risalah akhlak... Sebagaimana pula tidak pernah 
terpisah antara agama dan negara dan antara materi dan ruhani. Seorang Muslim yakin akan kesatuan hidup dan kesatuan kemanusiaan. Karena itu, tidak bisa diterima sama sekali tindakan pemisahan antara kehidupan dunia dan agama sebagaimana yang terjadi di Eropa. Demikian pula yang digembar-gemborkan oleh faham Kapitalis maupun lainnya." ${ }^{\text {36 }}$

Pertimbangan lain dari pernyataan itu - yang dalam hal ini tidak bisa dipisahkannya antara aktivitas ekonomi dan akhlak - karena nilai dan karakteristik ekonomi Islam itu adalah ekonomi ilahiah, ekonomi akhlak, ekonomi kemanusiaan dan ekonomi pertengahan. ${ }^{37}$ Ekonomi ilahiah dimaksudkan karena segala apa yang kita garap dalam perekonomian guna memenuhi kebutuhan hidup manusia pada hahikatnya adalah mutlak milik Allah, sedangkan manusia hanya sebatas menjalankan amanah dan oleh karena itu hanya sebagai pemilik semu (relatif) yang bersifat sementara. Selaku pemegang amanah, manusia harus tunduk dan taat pada acuan pemilik mutlak dalam beraktivitas ekonomi. Misalnya harus bersikap adil dan tidak melakukan kecurangan, karena kedlaliman, besar maupun kecil, disengaja ataupun tidak, jelas akan merugikan berbagai pihak. Bila hal ini terjadi maka perekonomian yang berbasis kemanusiaan tidak akan pernah terwujud karena tidak melindungi kepentingan orang lain yang seharusnya dipelihara. Demikian pula halnya bagi pelaku ekonomi dan pemilik harta, mereka harus menyadari bahwa harta yang mereka miliki di dalamnya ada hak orang lain yang wajib ditunaikan. Inilah esensi ajaran ekonomi Islam yang bersifat wasathiyah yang tidak menghendaki akumulasi kekayaaan pada segelintir manusia yang banyak melahirkan ketidakadilan atau kesenjangan. Pun juga, tidak dikehendaki terjadi penumpukan harta pada kekuasaan (negara) yang pada praktiknya memasung kepentingan dan kebebasan berusaha. Karena hal ini membatasi hak-hak individu yang seharusnya diberikan.

Itulah pokok-pokok pikiran Qardhawi seputar urgensi norma etika Islam dalam kegiatan ekonomi yang pantas menjadi bahan kajian dan renungan lebih dalam, baik di kalangan akademisi maupun para praktisi di dunia Islam, tanpa kecuali di Indonesia.

\section{Kiprah Dr. Yusuf Qardhawi : Sebuah Analisis}

Doktor Yusuf Qardhawi, putra kelahiran Mesir, seorang ulama besar, berwawasan luas (kosmopolit), ${ }^{38}$ mempunyai pandangan jauh ke depan 
(visioner), ${ }^{39}$ moderat, dan bersikap terbuka (fairness) ${ }^{40}$ karena kiprahnya di bidang dakwah pantas menjadi figur, uswah atau referensit ${ }^{\text {tl }}$ di kalangan komunitas muslim di manapun mereka berada. Uswah di sini tidak hanya dalam hal kecemerlangan intelektualnya, namun juga keberanian dan komitmennya dalam memperjuangkan tegaknya syariat Islam Ia menempuh pendidikan formal sejak tingkat dasar hingga pendidikan doktornya di negeri asalnya, Mesir. Namun bersamaan dengan itu, Qardhawi pernah pula mengenyam pendidikan non formal di penjara melalui rekan-rekan seniornya, antara lain Syaikh Muhammad Al-Ghazali dan Syaikh Sayyid Sabiq, yang juga sama-sama berstatus sebagai tahanan karena aktivitasnya di gerakan Ikhwanul Muslimin. ${ }^{42}$

Saat Mesir dipimpin Raja Faruk, Qardhawi masuk bui tahun 1949, saat usianya masih 23 tahun, karena keterlibatannya dalam pergerakan Ikhwanul Muslimin. April 1956, ia ditangkap lagi saat terjadi Revolusi Juni di Mesir. Bulan Oktober kembali ia mendekam di penjara militer selama dua tahun. Qardhawi dikenal sebagai pemberani sehingga sempat dilarang sebagai khatib di sebuah masjid di daerah Zamalik. Alasannya, khutbah-khutbahnya dinilai menciptakan opini umum tentang ketidakadilan rejim saat itu. ${ }^{43}$

Kiprah Qardhawi di bidang dakwah dapat dikategorikan ke dalam dua pola, yaitu pola terorganisir dan individual. Pola terorganisir dilakukan sejak usia muda setelah ia tertarik bergabung ke dalam gerakan Ikhwanul Muslimin. Ketertarikannya ke dalam gerakan ini karena ia sangat terkesan kepada mantan gurunya di bangku sekolah agama yang bernama Syaikh Al-Bahi Al-Khuli, ketua bidang penyebaran dakwah di Maktab Idari Ikhwanul Muslimin wilayah Barat pada saat itu. Di samping pula mengidolakan profil Syaikh Hasan Al-Banna yang mampu mengantarkan Ikhwanul Muslimin menjadi sebuah gerakan potensial karena konsep-konsepnya yang komprehensif dan fleksibel.

Melalui gerakan itulah Qardhawi banyak menimba pengalaman berorganisasi dan mempercepat proses pematangan intelektual dan wawasan karena seringkali berkomunikasi dengan tokoh-tokoh gerakan yang kredibilitas keilmuannya tidak diragukan lagi. Ini berarti Ikhwanul Muslimin telah menjadi sebuah kawah candradimuka bagi sosok Yusuf Qardhawi dalam menggali potensi dan menempa jati diri pribadinya. Dengan demikian, dengan terlibatnya ia sebagai aktivis gerakan, sekaligus dapat meraih dua keuntungan, yaitu di satu sisi ia memberi kepada orang lain melalui kiprah dakwahnya di kalangan masyarakat 
luas, khususnya di kalangan komunitas Ikhwanul Muslimin. Di sisi lain, ia banyak menerima dari orang lain yang mengantarkannya ia menjadi salah seorang ulama kaliber internasional di era globalisasi saat ini. Dalam hal ini bisa kita pahami dari pengakuan Qardhawi sendiri yang ia namakan sebagai refleksiku terhadap Ikhwanul Muslimin :

1. Ikhwan telah memperluas cakrawala pikiranku memahami Islam secara utuh sebagaimana disyariatkan Allah SWT, sebagaimana tertera dalam kitab-Nya, seperti diserukan Rasul-Nya dan dipahami oleh para sahabatnya.

2. Bergabungnya aku dengan Ikhwan telah memindahkan cita-citaku dari citacita lokal dan terbatas, pada cita-cita yang besar yang universal. Keinginannku tidak lagi tergantung pada masalah pribadiku tapi menjadi cita-cita yang terkait dengan umatku. ${ }^{44}$

Sedangkan pola individual, Qardhawi terus berkarya dan berdakwah baik dalam bentuk ceramah, tulisan maupun tindakan sebagaimana telah dijelaskan dalam uraian sebelumnya. Hanya saja semua ini tidak dilakukan Qardhawi di negeri yang melahirkannya, tetapi di negeri manca negara, yakni Qatar. Di negeri ini, ia bebas berekspresi sesuai potensi yang dimiliki, sebagai da'i, sebagai pelindung (guardian) bagi hukum, pembelajaran dan ortodoksi religius, sebagai nara sumber seminar, pimpinan perguruan tinggi, ketua kajian ilmiah dan sebagainya.

Pertanyaan kita sekarang adalah mengapa Qardhawi hijrah ke Qatar, rela meninggalkan negeri kelahiran yang ikut membesarkannya? Jawabnya mudah diprediksi karena dalam otobiografinya, ia sudah tidak sejalan lagi dengan penguasa Mesir yang telah menjebloskannya ke rumah tahanan yang merampas kemerdekaannya. Karena itu, Qardhawi yang merasa terpasung memilih untuk hijrah agar kebebasan ekspresinya terjamin demi kepentingan umat Islam di masa depan. Keputusan Qardhawi sama dengan keputusan Nabi Muhammad saw pada saat beliau memutuskan untuk hijrah dari negeri asalnya, Makkah, menuju negeri pilihannya, Madinah. Dalam sejarah, di negeri yang baru ini Rasulullah bebas melakukan dakwah dan membangun peradaban karena terbebas dari tekanan musuh-musuhnya sebagaimana pada saat berada di Makkah. Di negeri yang dianggap aman itulah Qardhawi sebagaimana Rasulullah bebas memerankan fungsi utamanya, beramar ma'ruf dan bernahi mungkar, sebuah amanah yang dibebankan kepada siapapun penegak kebenaran. Dengan kata lain, dalam situasi dan kondisi yang tidak lagi kondusif, hijrah pada akhirnya wajib dilaksanakan demi mengatur 
dan merubah strategi dakwah yang baru di tempat yang baru. Karena bagaimanapun di waktu sekarang atau di abad milineum ketiga ini perlu ada pembaharuan dakwah Islam ${ }^{45}$, agar bisa memberi harapan bagi umat Islam. Keputusan Qardhawi, juga seirama dengan keputusan Fazlur Rahman yang sejak 1970 harus hijrah ke Amerika Serikat (sebagai profesor dalam kajian Islam dalam berbagai aspeknya di Universitas Chicago) daripada menetap di Pakistan sebagai direktur Pusat Penelitian Islam di Karachi yang dijabatnya selama beberapa tahun ${ }^{46}$ Tujuan pokoknya adalah sama demi kebebasan dalam melakukan dakwah sesuai dengan profesinya masing-masing.

Setelah menetap di Qatar, Qardhawi benar-benar memanfaatkan kebebasan yang diraihnya dengan mengisi waktu bebasnya berkarya semaksimal mungkin. Beberapa karya monumentalnya yang diperkirakan berjumlah 91 buah buku telah beredar tidak saja di negeri Timur Tengah, bahkan ke seluruh dunia Islam. Hal ini merupakan bukti konkret dari kiprah Qardhawi dalam bidang dakwah yang diawalinya sejak ia masuk dalam Gerakan Islam, Ikhwanul Muslimin. Dakwah yang dilakukan tidak hanya dalam bentuk oral (verbal), namun dalam bentuk karya tulis sebanyak instrumen penyaluran ekspresi pemikirannya, termasuk pemikiran tantang etika ekonomi yang berbasis Islam.

\section{E. Kesimpulan}

Bertolak dari kajian di atas dapatlah dipahami bahwa sosok Yusuf Qardhawi adalah merupakan representasi ulama akhir abad kedua puluh dan awal abad kedua puluh satu saat ini. Dengan bekal potensi intelektual yang sangat memadahi dan ditopang dengan pengalaman empirik yang dilaluinya, ia pantas mendapat julukan tidak saja sebagai seorang 'ulama, bahkan lebih pas sebagai seorang 'allamah. Dengan sebutan ini Profesor Doktor Yusuf Qardhawi sangatlah memungkinkan banyak memberikan kontribusi pemikirannya melalui ranah dakwah yang digeluti sejak usia muda yang berawal setelah bergabung dalam Gerakan Ikhwanul Muslimin, sebuah Gerakan Islam yang sangat dikenal sampai saat ini.

Sejak mengawali peran ke-ulamaan-nya, Yusuf Qardhawi telah mengalami proses dialektika antara potensi dirinya dengan faktor-faktor eksternal yang sangat kondusif, terutama di lingkungan para tokoh Ikhwanul Muslimin, seperti Syaikh Hasan Al -Banna, Syaikh Muhammad Al- Ghazali dan Syaikh Sayyid Sabiq. 
Lingkungan inilah yang telah turut membentuk sosok Yusuf Qardhawi menjadi seorang yang sangat produktif dalam dakwah, berwawasan luas jauh ke depan, demokratis, dan akomudatif, yang pada akhimya mengantarnya menjadi figur yang layak menjadi referensi bagi masyarakat di Dunia Islam.

Belajar dari kunci sukses Yusuf Qardhawi dalam berkiprah di dataran dakwah, baik secara terorganisir (terstruktur) di lingkaran Ukhwanul Muslimin maupun yang ditekuni secara individual, pada akhirnya semakin meyakinkan kita bahwa nama besar seseorang selalu dibentuk, atau merupakan hasil interaksinya dengan pihak-pihak lain yang membesarkannya. Dengan kata lain, proses popularitas seseorang dalam bidangnya pasti melalui proses pematangan diri dalam suatu atmosfer yang mendukungnya. Atmosfer Ikhwanul Muslimin itulah yang telah menghegemoni pribadi Yusuf Qardhawi yang pada akhirnya ia menemukan dirinya sendiri sebagai seorang ulama yang banyak memberi kontribusi di Dunia Islam.

Dalam konteks Indonesia tesis itu bisa diperkuat dengan bukti-bukti aktual yang banyak dialami oleh nama besar para tokoh dalam berbagai Gerakan Islam yang mengantar mereka tidak saja dikenal di Indonesia, namun juga di dunia International. Dalam hal ini bisa kita ambil contoh, K.H. Ahmad Dahlan, K.H. A.R. Fachruddin dan A. Syafii Maarif dengan gerakan Muhammadiyah-nya, K.H. Hasyim Asy'ari, K.H. Abdurrahman Wahid dan K.H. Hasyim Mudzadi dengan gerakan Nahdlatul Ulama-nya dan yang pernah dialami Nurcholih Madjid dengan Himpunan Mahasiswa Islam-nya. Gerakan-gerakan ini telah memberi ruang berekpresi, berkreasi, dan berinovasi kepada mereka dalam bidang pemikiran, dakwah, sosial, pendidikan, ekonomi dan sebagainya, sejalan dengan apa yang dialami oleh Yusuf Qardhawi dalam bidang dakwah. Dengan perkataan lain, keberhasilan seorang tokoh dalam menjalankan perannya tidak cukup berjalan secara individual, namun perlu ada sebuah kendaraan yang ikut mengantarnya ke puncak sukses dan meraih popularitas.

Wallahu a'lam bisshawab. 


\section{Endnotes}

1 Hiroko Horikoshi, Kyai dan Perubahan Sosial (ter. Umar Basalim dan Andi Muarly Sunwara)(Jakarta:Perhimpunan Pengembangan Pesantren dan Masyarakat, 1987), 10

2 Ibid., 114. Oleh karena diskursus ini tidak mungkin menjelaskan peran 'ulama secara detail, maka persilakan pembaca membaca paparan Horikoshi tentang fungsi keulamaan sebagai rekaman dari hasil penelitian yang telah dilakukan. Dalam hal ini, ia mengkaji cukup panjang bagaimana peran-peran yang dimainkan ulama di masyarakat dalam halaman 114-148

3 Nikki R. Keddie (ed), Scholars, Saints, and Sufis (California : University of California Press, 1978), 2

4 Ibid

5 Ibid

$6 \quad$ Ibid., 4

7 Ibid., 9

8 Profil ini disadur dari internet www.qaradawi.com (october, 2003), 1-2, di samping dari sumber lain yang relevan

9 Yusuf Qardhawi, Kenanganku Bersama Ikhwanul Muslimin(Penerjemah M. Lili Nur Aulia) (Jakarta : Aulia Publisher, 2003), xiv

10 Ibid

"I Ibid., $\mathrm{xV}$

12 Ibid

13 M. Natsir, Fiqhud Da'wah (Djakarta : Penerbit Madjalah Islam Kiblat, 1969), 2

I4 Al-Qur'an dan Terjemahnya, (Jakarta : Departemen Agama, 1071), 688

15 H.M. Arifin, Psikologi Dakwah (Jakarta : Bumi Aksara, 1993), 6

16 Ibid

17 Amin Ihsan Islahi, Serba-Serbi Dakwah (Penerjemah Luqman Hakim) (Bandung : Penerbit Pustaka, 1989), 16

18 Ibid., 17

19 Yusuf Qardhawi, Prioritas Gerakan Islam, Antisipasi Masa Depan Gerakan Islam (Penerjemah A.Najiyulloh) (Jakarta : Al-Ishlahy Press, 1414 H/ 1993 M), 5

20 Ibid.

21 Yusuf Qardhawi, Kenanganku ...., xvii

22 Ali Abdul Halim Mahmud, Ikhwanul Muslimin Konsep Gerakan Terpadu Jilid I (Penerjemah Syafril Halim) (Jakarta : Penerbit Gema Insani Press, 1997), 66 
23 Rahmat Tohir Ashari, Konsep Pergerakan Ikhwan Al-Muslimin : Upaya Mengenal Hasan Al-Banna Lebih Dekat dalam M. Aunul Abied Shah et al, Islam Garda Depan, Mosaik Pemikiran Islam Timur Tengah (Jakarta : Penerbit Mizan), 67

24 Ibid., 68

2s Yusuf Qardhawi, Kenanganku ..., xxv

26 Ibid., Xxi

27 Ibid, xxi-xxii

28 Ibid

29 Ibid., XXV

30 Ibid., 3

31 Ibid., 7

32 Ibid., 14

33 Ibid

$34 \quad$ Ibid., 174

3s Ibid., 45-49

36 Yusuf Qardhawi, Peran Nilai dan Moral Perekonomian Islam, ter. K.H. Didin Hafidhuddin, M.Sc. (Jakarta : Robbani Press, 1977), 57

37 Ibid., 23

38 Sebagai indikator bahwa ia seorang kosmopolitan bisa terbaca dari berbagai ragam karya tulisnya yang antara lain tergambar di atas. Nampaknya sikap ini termotivasi oleh pernyataannya sendiri bahwa: "Islam yang telah disyariatkan Allah tidak membiarkan satupun dari aspek kehidupan. Karena Islam -wataknya-adalah universal, mencakup segala aspek hidup dan kehidupan : material dan spiritual, personal dan sosial. ... Islam menolak parsialisasi hukum dan ajaran-ajarannya. ...Kehidupan adalah satu kesatuan yang tidak terpisah-pisah" Statmen ini terangkum dalam sebuah bukunya yang berjudul Nahwa Wahdah Fikriyah lil 'Amilin lil Islam yang telah diterjemahkan ke dalam bahasa Indonesia. Karenanya lihat Yusuf Qardhawi, Menuju Kesatuan Fikrah Aktivis Islam : Totalitas Islam (Penerjemah A. Najiyulloh) (Jakarta : Robbani Press, tt), 70 - 78

Selanjutnya sikap kosmopolit itu bisa terbentuk dari prinsip yang ia pegang teguh yakni tidak setuju mendikotomikan antara ilmu agama dan ilmu umum karena pemisahan secara dikotomis menurutnya bisa menghambat kemajuan Islam itu sendiri.

Sebagai seorang visioner bisa ditangkap dari pandangan-pandangannya yang jauh ke depan yang terinspirasi oleh pendapatnya bahwa "Karakteristik pemikiran ilmiah yang dicita-citakan untuk Gerakan Islam itu ialah pemikiran masa depan yang senantiasa menatap ke depan, dan tidak terbatas hanya sampai hari ini. 
Tidaklah aneh, jika Gerakan Islam senantiasa memperhatikan masa depan. Sebab, itu adalah logika Islam yang tersimpan di dalam Al-Qur'an dan Sunnah Rasulullah saw" Pernyataan ini tertera dalam karya tulisnya yang berjudul Awlawiyyat AlHarakat Al-Islamiyyah fi Al-Marhalah Al-Qadimah yang sudah diterjemahkan ke dalam bahasa Indonesia. Untuk itu lihat Yusuf Qardhawi, Prioritas Gerakan Islam : Antisipasi Masa Depan Gerakan Islam (Penerjemah A. Najiyulloh) (Jakarta : AlIshlahy Press, 1414 H/ 1993 M), 141

Sikap moderat dan fairness ini bisa dibaca dalam keluarga yang memberi kebebasan kepada putra-putrinya untuk menuntut ilmu sesuai dengan minat dan bakatnya masing-masing tanpa membedakan gender sebagaimana terlukis dalam uraian sebelum ini. Dalam urusan ilmiah, dakwah dan gerakan, ia mempunyai statmen : "Di antara ciri dan karakteristik pemikitran ilmiah ialah pemikiran yang moderat, baik itu orientasinya ataupun kecenderungannya. Pemikitan seperti itu menggambarkan sebuah pandangan yang moderat dan integral terhadap masyarakat dan kehidupan. Suatu manhaj yang mencerminkan visi moderasi umat moderat, yang jauh dari ektrimis dan sikap cengeng. . . Moderasi menurut pendapat saya akan melahirkan kemudahan. Sebab ia moderat dalam arti antara keras membantu di satu sisi dan lunak yang serba menghalalkan di sisi lain". Ibid., 133-136

Selanjutnya dalam bukunya yang lain, Ash Shahwah Al-Islamiyah, Bainal Ikhtilafil Masyru'wat Tafarruqil Madzmum, ia menyatakan : "Saya pun tidak resah kalau di dalam tubuh Kebangkitan Islam itu terdapat berbagai madrasah, kelompok atau jema'ah, yang masing-masing memiliki manhaj tersendiri dalam berkhidmat dan berjuang menegakkan Islam di muka bumi, sesuai dengan penentuan sasaran, skala prioritas, sasaran dan tahapannya. Saya tidak termasuk orang-orang yang bermimpi menginginkan dan menyerukan kepada satu jama'ah atau Gerakan Islam yang akan menghimpun semua aktivis Islam dalam satu sistem dan di bawah satu pimpinan. Terlalu banyak kendala yang merintanginya, di samping ambisi yang memang tidak pada tempatnya" Lihat Yusuf Qardhawi, Gerakan Islam, Antara Perbedaan yang Dibolehkan dan Perpecahan yang Dilarang (Penerjemah Aunur Rafiq Shaleh Tamhid) (Jakarta : Robbani Press, 1991), 4

4) Dalam realitas, sebagai ulama yang mumpuni, YusufQardhawi pantas menjadi profil, figur, uswah atau referensi bagi umat Islam. Dalam hal ini kita akui dari pernyatannya bahwa “ Hampir setiap hari saya menerima surat dari berbagai penjuru Dunia Islam, mengadukan tentang para da'i dan aktivis Islam yang tidak punya kesibukan kecuali menimbulkan perselisihan dan menyebarkan tuduhan kepada para hamba Allah. Tanpa mempertimbangkan realitas, situasi, kondisi darurat dan bencana yang telah melanda masyarakat", Ibid., 6

42 Berkaitan dengan pengalaman pendidikan nonformal ini diakui sendiri, bahwa ia banyak sekali menimba ilmu dari para seniornya selama di penjara. Pengalaman ini ia 
sebut sebagai training abadi bagi Ikhwan, baik selama dalam penjara Ath-Thur, selanjutnya ke Haiktasib, sampai akhirnya kembali lagi ke penjara Ath-Thur. Pengakuan ini bisa diperjelas dari beberapa pernyataannya : "Selanjutnya setelah shalat fajar, kami membaca Al Matsurat seperti yang kuceritakan sebelum ini. Setelah itu kami berkumpul dalam halaqah kajian bersama sejumlah tokoh Ikhwan senior untuk mendiskusikan beberapa tema agama dan ilmiah populer. Halaqah Sirah Nabawiyah Ibersama Syaikh Al Ghazali, halaqah fiqih bersama Syaikh Sayyid Sabiq. Dan terkadang ada juga halagah lain yang dipimpin oleh Ikhwan lain seperti Ustadz Abdul Badi Shagr yang membahas tema "Bagaimana Kita Menyeru Manusia". ... Para tahanan menggunakan waktu mereka dengan berbagai aktivitas. Ada di antara kami yang membaca buku, ketika suasananya memungkinkan. Aku sendiri membawa dua buku, yakni buku Ihya Ulumiddin karya Imam Al Ghazali yang dihadiahkan oleh tetanggaku Syaikh Byumi Ghazuni, dan beberapa jilid kitab Al Aqd Al Fariid karya Ibnu Abd Rabbah yang berbicara masalah sastra. Aku manfaatkan waktu untuk membaca kitab-kitab itu. Sesekali aku mendiskusikan isinya dengan para Ikhwan. Kami juga mengadakan sejumlah acara bersama di waktu malam, untuk menghibur jiwa sebagaimana dikatakan oleh Rasulullah saw kepada Hanzalah: "Ya Hanzalah sekali begini dan sekali begitu." Kalimat itu menganjurkan kita mengisi waktu secara variatif dengan berbagai kegiatan". Lihat Yusuf Qardhawi, Kenanganku Bersama Ikhwanul Muslimin, Op.cit., 99-119

Dalam konteks Indonesia, pengalaman berharga seperti itu mengingatkan kita pada pengalaman HAMKA selama menjalani proses penahanan di penjara karena berseberangan dengan perintah Orde Lama pasa saat itu yang dipimpin persiden pertama, Soekarno. Sebagai sosok ulama yang produktif dalam dakwah, baik dalam bentuk ceramah maupun karya tulis, HAMKA sempat menghasilkan sebuah karya monumentalnya yakni Tafsir Al-Qur'an lengkap 30 juz yang diberi nama $A l-A z h a r$.

Sebagai sosok ulama yang kredibilitasnya tidak saja diakui di Indonesia, bahkan dunia Internasional, sampai sekarang buku tafsir itu tetap menjadi maraji' para akademisi dan masyarakat luas.

43 Ibid., xiv

44 Ibid., $41-44$

45 Ahmad Syafi'I Ma'arif, Pembaharuan Dakwah Islam, dalam H.M. Amin Rais, dkk, Islam Multidimensional (Yogyakarta : Penerbit Lembaga Penelitian, Pengembangan Pendidikan dan Teknologi Yogyakarta dan Kelompok Studi Teknosofiah, 1986), 57

46 Ahmad Syafi'I Ma'arif, Sebuah Pengantar : Fazlur Rahman, Al-Qur'an dan Pemikiran Islam dalam Fazlur Rahman, Islam (Penerjemah Ahsin Mohammad) (Bandung : Penerbit Pustaka, 1984), vi-vii 


\section{Bibliography}

Al-Qur'an dan Terjemahnya. Jakarta : Departemen Agama, 1971

Arifin, H.M, Psikologi Dakwah. Jakarta ; Bumi Aksara, 1993

Ashari, Rahmat Tohir, Konsep Pergerakan Ikhwan Al-Muslimin : Upaya Mengenal Hasan Al-Banna Lebih Dekat dalam M. Aunul Abied et al, Islam Garda Depan, Mosaik Pemikiran Islam Timur Tengah. Jakarta : Miza

Horikoshi, Hiroko, Kyai dan Perubahan Sosial (Penerjemah Umar Basalim dan Andi Muarly Sunrawa). Jakarta : Perhimpunan Pengembangan Pesantren dan Masyarakat, 1987

Islahi, Amin Ihsan, Serba-Serbi Dakwah (Penerjemah Luqman Hakim), Bandung: Pustaka, 1989

Keddie, Nikki R (ed). Scholars, Saints, and Sufis. California : University of California Press, 1978

Ma'arif, Ahmad Syafi'i, Pembaharuan Dakwah Islam, dalam H.M. Amin Rais, dkk., Islam Multidimensional. Yogyakarta : Lembaga Penelitian, Pengembangan Pendidikan dan Teknologi Yogyakarta dan Kelompok Studi Teknosofiah, 1986

, Sebuah Pengantar : Fazlur Rahman, Al-Qur'an dan Pemikiran Islam. dalam Fazlur Rahman, Islam (Penerjemah Ahsin Mohammad), Bandung: Pustaka, 1984

Madjid, Nurcholish, Ulama Bukanlah Pendeta. dalam Elza Peldi Taher (ed), PintuPintu Menuju Tuhan. Jakarta : Paramadina, 2002

Mahmud, Ali Abdul Halim, Ikhwanul Muslimin Konsep Gerakan Terpadu Jilid I (Penerjemah Syafril Halim). Jakarta : Gema Insani Press, 1997

Natsir, M., Fiqhud Da'wah. Djakarta : Majalah Islam Kiblat, 1969

www. Qaradawi.com (October, 2003)

Qardhawi, Yusuf, Daurul Qiyam wal Akhlaq fil Iqtishadil Islami cet I Kairo, Mesir : Maktabah Wahbah, 1415 H/199 
Kenanganku Bersama Ikhwanul Muslimin cet I (Penerjemah M. Lili Nur Aulia). Jakarta : Aulia Publisher, 1423 H / 2003 M , Haruskah Hidup dengan Riba, cet VI (Penerjemah H Salim Basyarahil). Jakarta : Gema Insani Press, 1417 H / 1996 M

, Menuju Kesatuan Fikrah Aktivis Islam (Penerjemah A. Najiyulloh).Jakarta : Robbani Press, tt , Gerakan Islam, Antara Perbedaan yang Dobolehkan dan Perpecahan yang Dilarang cet. I (Penerjemah Aunur Rafiq Shaleh Tamhid) Jakarta : Robbani Press, 1991 - Prioritas Gerakan Islam, Antisipasi Masa Depan Gerakan Islam (Penerjemah A. Najiyulloh) Jakarta : Al Ishlahy Press, 1414 H / $1993 \mathrm{M}$ 